\title{
Korelasi ukuran badan, volume ambing dan produksi susu kambing Peranakan Etawah (PE) di Kecamatan Turi Kabupaten Sleman Yogyakarta
}

\section{Correlation of body size, udder and milk production of Peranakan Etawah goat $(\mathrm{PE})$ in Turi District of Sleman Regency Yogyakarta}

\author{
Dwi Nurul Febriana*, Diah Wahyu Harjanti, dan Priyo Sambodho \\ Fakultas Peternakan dan Pertanian, Universitas Diponegoro \\ Jl. Prof. H. Soedarto, S.H. - Tembalang Semarang, Indonesia (50275)
}

Submitted: 27 May 2018, Accepted: 04 July 2018

\begin{abstract}
ABSTRAK: Penampilan luar ternak dapat digunakan untuk selesksi ternak. Ukuran badan dan ambing dapat digunakan untuk menilai produktifitas ternak. Penelitian ini bertujuan untuk mengetahui korelasi antara ukuran badan (panjang badan, tinggi pundak dan lingkar dada), volume ambing dan produksi susu. Materi yang digunakan adalah 35 ekor kambing PE laktasi pada periode laktasi II-III dan bulan laktasi 4-5. Analisis yang digunakan adalah regresi korelasi linier sederhana dan non-linier kuadratik. Hasil menunjukan bahwa produksi susu dan volume ambing tidak mengalami peningkatan seiring pertambahan panjang badan. Tinggi pundak dengan volume ambing dan produksi susu memiliki korelasi yang tidak nyata. Keseluruhan perhitungan menunjukan bahwa tidak ada hubungan antara lingkar dada, volume ambing dan produksi susu pada ternak. Volume ambing dengan produksi susu menunjukan korelasi yang yang kuat. Kesimpulan yang didapat bahwa tidak ada hubungan antara panjang badan, tinggi pundak dan lingkar dada dengan volume ambing dan produksi susu. Korelasi antara volume ambing dengan produksi susu adalah semakin besar volume ambing maka semakin besar produksi susu yang dihasilkan.
\end{abstract}

Kata Kunci: Kambing PE, Ukuran Badan, Volume Ambing, Produksi susu

\begin{abstract}
The outer performance can be used for livestock selection. Body size and udder can be used to assess livestock productivity. This study aimed to determine the correlation between body size (body length, shoulder height and chest size), udder volume and milk production. The material used were 35 lactation PE goats in the lactation period of II-III and lactation month of 4-5. The analysis used was simple linear correlation regression and non-linear quadratic. The results showed that milk production and udder volume did not increase during the increasing of body length. Shoulder height with udder volume and milk production have unreal correlation. The overall calculation shows that there is no relationship between chest size, udder volume and milk production in livestock. The udder volume with milk production shows a strong correlation. In conclusion, there is no relationship between body length, shoulder height and chest size with udder volume and milk production. The correlation between udder volume and milk production is more udder volume, more milk can be produced.
\end{abstract}

Keywords: PE goat, body size, udder volume, milk production.

*Corresponding Author: dwinurulfebriana@gmail.com

DOI: 10.21776/ub.jiip.2018.028.02.06 


\section{PENDAHULUAN}

Kambing perah merupakan salah satu jenis ternak yang biasanya dimanfaatkan untuk menghasilkan susu, daging dan bibit. Kambing perah yang banyak di ternakkan salah satunya yaitu jenis Kambing Peranakan Etawah (PE). Faktor kemampuan adaptasi yang tinggi kambing PE terhadap kondisi di Indonesia merupakan salah satu alasan jenis ternak tersebut banyak dipilih oleh peternak. Usaha kambing perah di Indonesia saat ini mulai adanya peningkatan. Peternak mulai sadar bahwa kambing perah memiliki potensi yang tinggi untuk dikembangkan. Peningkatan ini dapat membantu kegiatan pemerintah dalam memenuhi kebutuhan akan protein hewani terutama susu. Beternak kambing perah untuk mendapatkan keuntungan yang maksimal diperlukan kambing laktasi yang memiliki produksi yang tinggi. Produktifitas kambing perah dipengaruhi oleh beberapa faktor antara lain faktor genetis seperti jenis ternak, keturunan, umur, hormon, kebuntingan dan ukuran badan serta faktor lingkungan seperti faktor pakan, musim, lama laktasi, pemerahan, penyakit dan obat-obatan (Mukhtar, 2006).

Memilih ternak dapat dilakukan dengan melihat catatan (recording) produksi ternak. Namun hal ini sulit dilakukan karena beberapa peternakan tidak memiliki catatan produksi ternak. Hal tersebut maka perlu dilakukan penelitian lebih lanjut dengan cara memperhatikan eksterior ternak yang berkaitan dengan tipe perah diharapkan dapat digunakan untuk menentukan keterkaitan antar variabel dan jumlah produksi susu ternak perah tersebut yang dapat dimanfaatkan untuk meningkatkan mutu genetik ternak. Ukuran badan ternak merupakan cerminan pertumbuhan dan perkembangan ternak (eksterior) sehingga diharapkan dapat memberikan gambaran mengenai penampilan produksi yang dihasilka (Taofik dan Depison, 2008). Tujuan dari penelitian ini antara lain untuk mendapatkan rumus dugaan atau estimasi hubungan antara ukuran badan, volume ambing dan produksi susu kambing PE.

\section{MATERI DAN METODE}

\section{Materi}

Materi yang digunakan dalam penelitian ini adalah 35 ekor kambing PE laktasi pada periode laktasi II-III dan bulan laktasi 4-5 dengan frekuensi pemerahan 2 kali. Peralatan yang digunakan yaitu pita ukur butterfly untuk mengukur lingkar badan, tongkat ukur untuk menggukur panjang badan dan tinggi pundak, wadah berkapasitas 2 liter untuk mengukur volume ambing, gelas ukur kapasitas $500 \mathrm{ml}$ dan 1 liter untuk mengukur jumlah produksi susu.

\section{Metode penelitian}

Penelitian ini diawali dengan melakukan survey yang dilaksanakan satu bulan sebelum pengamatan Penentuan dan survei lokasi penelitian yaitu terletak di Kecamatan Turi, Kabupaten Sleman, Yogyakarta. Selanjutnya pengukuran ukuran badan berupa panjang badan, tinggi pundak, dan lingkar dada. Pengukuran panjang badan dimulai dari pada ruas tulang belakang ketiga dan keempat dengan skala $\mathrm{cm}$ dengan menggunakan tongkat ukur secara lurus dengan menggunakan pita ukur dengan satuan $\mathrm{cm}$. Tinggi pundak ternak diukur dari titik tertinggi pundak hingga tanah menggunakan tongkat ukur sengan satuan $\mathrm{cm}$. Lingkar dada ternak diukur dengan cara melingkarkan pita ukur di sekeliling rongga dada secara tegak lurus dengan sumbu badan dengan satuan $\mathrm{cm}$ (Adriani, 2011). Pengukuran Volume Ambing dilakukan sebelum pemerahan dan setelah pemerahan dengan menggunakan wadah berbahan plastik yang berukuran 2 liter. Metode yang digunakan dalam pengukuran volume ambing yaitu metode "Air Tumpah" menurut hukum Archimides (Pribadiningtyas dkk., 2012). Serta pengukuran produksi susu.

Data yang diperoleh kemudian dianalisis dengan analisis regresi korelasi linier sederhana dan non-linier kuadratik dengan bantuan program SPSS 16.0 
HASIL DAN PEMBAHASAN

Berdasarkan pengukuran ukuran badan (panjang badan, tinggi pundak, dan lingkar dada), volume ambing, serta produksi susu yang telah dilaksanakan didapatkan kisaran dan rata-rata yang tercantum pada tabel 1 .

Tabel 1. Hasil perhitungan panjang badan, tinggi pundak, lingkar dada, volume ambing, dan produksi susu.

\begin{tabular}{lll}
\hline \multicolumn{1}{c}{ Parameter } & \multicolumn{1}{c}{ Kisaran } & Rata-rata \\
\hline Panjang badan $(\mathrm{cm})$ & $61,25-90,25$ & 72,31 \\
Tinggi pundak $(\mathrm{cm})$ & $66,50-85,25$ & 75,97 \\
Lingkar dada $(\mathrm{cm})$ & $75,50-95,00$ & 83,75 \\
Volume ambing pagi $(\mathrm{ml})$ & $340-710$ & 546 \\
Volume ambing sore $(\mathrm{ml})$ & $250-570$ & 403,71 \\
Produksi susu $(\mathrm{ml})$ & $75,71-580$ & 296,37 \\
\hline
\end{tabular}

Rataan ukuran panjang badan kambing PE yang diteliti sebesar $72,31 \mathrm{~cm}$, tinggi pundak sebesar 75,97 cm, dan lingkar dada sebesar 83,75 cm. Menurut Badan Standarisasi Nasional (2015) indukan kambing PE yang baik memiliki ukuran minimal pada panjang badan $65 \mathrm{~cm}$, tinggi badan $69 \mathrm{~cm}$, dan lingkar dada $72 \mathrm{~cm}$. Ternak yang baik sebaiknya memiliki ukuran badan yang seimbang untuk produksi yang lebih unggul. Hendrich (2008) menjelaskan bahwa kondisi badan kambing perah tidak boleh terlalu kurus karena vitalitas rendah, produksi susu rendah, dan biasanya menghasilkan anak yang cenderung lebih kecil. Namun, kambing juga tidak boleh terlalu berlemak karena akan kesulitan melahirkan, kemungkinan terjangkit ketosis tinggi, dan produksi susu yang rendah. Ternak dari penelitian ini memiliki ukuran tubuh yang normal dan baik. Namun, setiap ternak memiliki ukuran badan yang berbeda-beda. Perbedaan ukuran badan pada masing-masing ternak karena setiap ternak mempunyai perbedaan tingkat pertumbuhan pada badannya (Mardhianna dkk., 2015).

Berdasarkan hasil pengukuran didapatkan rata-rata volume ambing pagi sebesar $546 \mathrm{ml}$ dan volume ambing sore sebesar 403,71 ml. Ukuran volume ambing pada setiap kambing berbeda-beda. Ukuran ambing tergantung pada umur, faktor genetik, masa laktasi dan jumlah susu didalamnya (Mukhtar, 2006).. Perbedaan volume ambing pagi dan sore dikarenakan produksi susu yang dihasilkan berbeda akibat interval pemerahan yang tidak sama. Pemerahan pagi hari dilaksanakan pukul 6.30 WIB sedangkan pemerahan sore dilaksanakan pukul 16.00 WIB. Menurut penelitian yang dilaksanakan Pasaribu dkk., (2015) interval pemerahan memiliki hubungan dengan produksi susu, dimana interval pemerahan semakin lama maka produksi susu meningkat, sebaliknya interval pemerahan menurun maka produksi susu juga menurun.

Berdasarkan pengukuran didapatkan hasil bahwa rata-rata produksi susu yang dihasilkan kambing PE yaitu sebesar 296,37 ml. Hasil ini lebih rendah dari penelitian Ramadhan dkk., (2013) yang menghasilkan 320,66 - 340,12 ml, serta hasil penelitian taofik dan depison (2008) yang memiliki hasil $390 \mathrm{ml}$. Devendra dan Burns (1994) menyatakan bahwa ternak dapat mencapai produksi susu yang tinggi pada umur 4-5 tahun. Hasil susu yang diproduksi masing-masing ternak juga berbeda, hal ini dapat disebabkan karena faktor genetik, perbedaan ukuran badan, kebuntingan, dan kesehatan ternak. (Mukhtar, 2006) menyatakan bahwa Perbedaan produksi susu disebabkan oleh faktor genetik yang meliputi variasai individual, keturunan, lama laktasi dan persistensi, hormonal, kebuntingan dan ukuran badan. Faktor kedua yaitu lingkungan yang meliputi pakan, pemerahan, perawatan, penyakit, dan obat-obatan. 
Hubungan antara panjang badan dengan volume ambing dan produksi susu

Hasil pengukuran panjang badan (PB) kambing PE dengan volume ambing
(VA) dan produksi susu (PS) menunjukan bahwa persamaan regresi serta koefisien korelasi dan determinasi dapat dilihat pada Tabel 2.

Tabel 2. Persamaan regresi, koefisien korelasi $(r)$, koefisien determinasi $\left(\mathrm{R}^{2}\right)$ dan $P$ value analisis regresi antara panjang badan dengan VA pagi (VAp) dan produksi susu (PS).

\begin{tabular}{llccc}
\hline \multicolumn{1}{c}{ Ukuran Badan } & \multicolumn{1}{c}{ Persamaan Regresi } & r & $\mathrm{R}^{2}$ & P value \\
\hline PB \& VAp & a. $\hat{y}=321,01+2,13 \mathrm{x}$ & 0,140 & 0.023 & 0,388 \\
& b. $\hat{y}=616,22-4,45 \mathrm{x}+0,05 \mathrm{x}^{2}$ & 0,153 & 0,023 & 0,504 \\
PB\& PS & a. $\hat{y}=6,65+4,01 \mathrm{x}$ & 0,165 & 0.027 & 0,342 \\
& b. $\hat{y}=3995,75-104,53 \mathrm{x}+0,73 \mathrm{x}^{2}$ & 0,331 & 0,110 & 0,155 \\
\hline
\end{tabular}

Keterangan: $\quad \mathrm{a}=$ Hubungan Pola Linier

$\mathrm{b}=$ Hubungan Pola non-linier kuadratik

Hasil analisis regresi linier sederhana dan regresi non-linier kuadratik menunjukan bahwa produksi susu dan volume ambing tidak mengalami peningkatan seiring pertambahan panjang badan karena keseluruhan menunjukan tidakadanya hubungan. Hasil ini sama dengan penelitian Saputra dkk., (2013) pada ternak sapera dihasilkan bahwa panjang badan memiliki hubungan yang tidak nyata dengan produksi susu. Hal ini diduga karena produksi susu dipengaruhi oleh faktor lain.
Faktor seperti bangsa, pakan, laktasi, ukuran ambing, dan kemampuan adaptasi ternak dapat mempengaruhi produksi susu (Solaiman, 2010)

\section{Hubungan antara tinggi pundak dengan volume ambing dan produksi susu}

Hasil pengukuran tinggi pundak (TP) kambing PE dengan volume ambing dan produksi susu menunjukan bahwa persamaan regresi serta koefisien korelasi dan determinasi dapat dilihat pada Table 3.

Tabel 3. Persamaan regresi, koefisien korelasi (r), dan koefisien determinasi $\left(\mathrm{R}^{2}\right)$, dan $\mathrm{P}$ value analisis regresi antara tinggi pundak dengan volume ambing pagi (VAp) dan produksi susu (PS)

\begin{tabular}{llccc}
\hline Ukuran Badan & \multicolumn{1}{c}{ Analisis Regresi } & $\mathrm{r}$ & $\mathrm{R}^{2}$ & $\mathrm{P}$ value \\
\hline TP\& VAp & a. $\hat{\mathrm{y}}=163,39+5,04 \mathrm{x}$ & 0,247 & 0.061 & 0,153 \\
& b. $\hat{\mathrm{y}}=-2709,18+81,36 \mathrm{x}+0,51 \mathrm{x}^{2}$ & 0,270 & 0,073 & 0,299 \\
TP \& PS & a. $\hat{\mathrm{y}}=-267,71+7,42 \mathrm{x}$ & 0,262 & 0,069 & 0,128 \\
& b. $\hat{\mathrm{y}}=1572,25-41,48 \mathrm{x}+0,32 \mathrm{x}^{2}$ & 0,267 & 0,071 & 0,306 \\
\hline
\end{tabular}

Keterangan : $\quad \mathrm{a}=$ Hubungan Pola Linier

$\mathrm{b}=$ Hubungan Pola Kuadratik

Hasil analisis menyatakan bahwa tinggi pundak dengan volume ambing dan produksi susutidak memiliki hubungan. Tidak semua ukuran badan ternak memiliki korelasi dengan produksi susu. Menurut penelitian Saputra dkk., (2013) mengenai hubungan panjang badan, tinggi pundak dan lingkar dada pada produksi susu menyatakan tinggi pundak tidak memiliki koreasi dengan produksi susu karena tinggi pundak dan produksi susu dipengaruhi oleh faktor lain seperti umur, kesehatan, jumlah anak yang dilahirkan, serta factor lingkungan.

\section{Hubungan antara lingkar dada dengan volume ambing dan produksi susu}

Hasil pengukuran lingkar dada (LD) kambing PE dengan Volume Ambing dan produksi susu (PS) menunjukan bahwa persamaan regresi serta koefisien korelasi dan determinasi dapat dilihat pada tabel 4 . 
Tabel 4. Persamaan regresi, koefisien korelasi (r), koefisien determinasi (R), dan P value analisis regresi antara lingkar dada dengan VA pagi (VAp) dan produksi susu (PS)

\begin{tabular}{llccc}
\hline Ukuran Badan & \multicolumn{1}{c}{ Analisis Regresi } & r & $\mathrm{R}^{2}$ & P value \\
\hline LD \& VAp & a. $\hat{y}=189,82+4,25 x$ & 0,196 & 0.039 & 0,523 \\
& b. $\hat{y}=7426,58-116,78 x+1,007 x^{2}$ & 0,270 & 0,012 & 0,592 \\
LD \& Prod Susu & a. $\hat{y}=19,82+3,30 x$ & 0,110 & 0.012 & 0,258 \\
& b. $\hat{y}=11120,09-259,03 x+1,55 x^{2}$ & 0,305 & 0,093 & 0,170 \\
\hline
\end{tabular}

Keterangan : $\quad \mathrm{a}=$ Hubungan Pola Linier

$\mathrm{b}=$ Hubungan Pola Kuadratik

Berdasarkan hasil analisis regresi linier sederhana dan kuadratik didapatkan keseluruhan perhitungan menunjukan bahwa tidak adanya hubungan antara lingkar dada dengan volume ambing dan produksi susu pada ternak. Hal ini dikarenakan faktor lain yang mempengaruhi peningkatan lingkar dada dan produksi susu. Budiarsana (2005) mengatakan, bahwa performa ternak dipengaruhi oleh beberapa faktor yang kompleks seperti manajemen pakan, dan lingkungan sehingga menyebabkan terjadinya perbedaan hasil pengukuran performa ternak. Penelitian yang telah dilakukan Saputra dkk., (2013) dihasilkan bahwa lingkar dada memiliki sumbangan relatif dan sumbangan efektif yang kecil karena tidak adanya hubungan antara lingkar dada dengan produksi susu. Hal ini kurang sesuai dengan penelitian yang dilaksanakan Jarmuji (2011) dengan hasil terdapat hubungan kuat antara lingkar dada dengan bobot badan dan produksi susu.

\section{Hubungan Antara Volume Ambing dan Produksi Susu}

Berdasarkan hasil analisis regresi linier sederhana antara volume ambing pagi dan produksi susu diperoleh persamaan $\mathrm{y}=-308,42+1,11 \mathrm{x}$. Hasil tersebut menunjukan bahwa adanya korelasi positif antara volume ambing dengan produksi susu. Hal ini sesuai dengan hasil penelitian Taofik dan Depison (2008) yang menunjukan terdapat adanya keeratan yang tinggi antara volume ambing dengan produksi susu. Koefisien korelasi sebesar 0,799 yang menunjukan bahwa terdapat hubungan yang kuat antara volume ambing pagi dengan produksi susu. Koefisien determinasi sebesar 0,639 yang artinya volume ambing pagi memberikan pengaruh besar sebanyak $63,9 \%$.

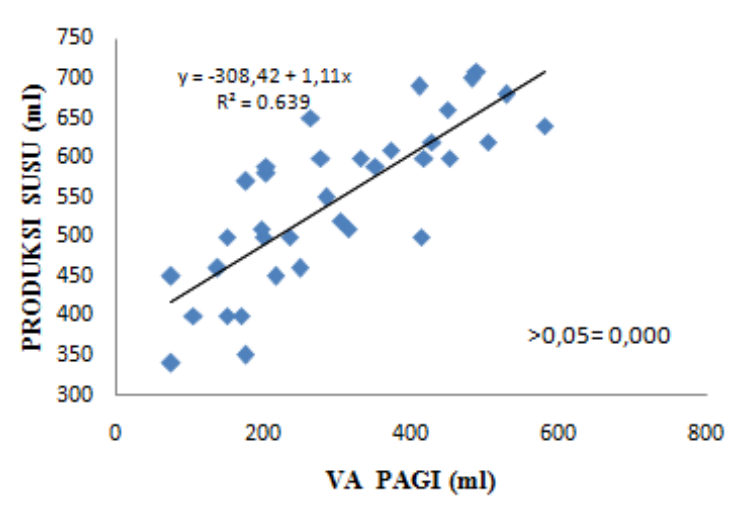

Gambar1. Persamaan Garis Regresi antara Volume ambing pagi dengan produksi susu

Korelasi antara volume ambing dengan produksi susu menunjukan bahwa setiap peningkatan volume ambing akan diikuti dengan meningkatnya produksi susu Sesuai pendapat Pribadiningtyas dkk., (2012) bahwa semakin besar volume ambing maka semakin besar pula produksi susunya. Ukuran ambing yang semakin besar memberikan indikasi peningkatan produksi susu. Volume ambing yang besar didalamnya mengandung sel sekretori yang besar juga yang berfungsi untuk mensekresikan susu (Habib dkk., 2014).

\section{KESIMPULAN}

Tidak ada hubungan antara panjang badan, tinggi pundak dan lingkar dada dengan volume ambing dan produksi susu. Namun, didapatkan korelasi positif pada volume ambing dengan produksi susu dimana semakin besar volume ambing maka semakin besar produksi susu yang dihasilkan. 


\section{DAFTAR PUSTAKA}

Adriani. 2011. Pertumbuhan dan Dimensi Tubuh Anak Kambing sebagai Respons Pemberian PMSG pada Induk sebelum Dikawinkan. Jurnal Ilmu-Ilmu Peternakan, 14(2), 103110.

Badan Standarisasi Nasional, B. 2015. SNI. 7352.1-2015. Jakarta: Badan Standarisasi Nasional.

Budiarsana, I. G. M. 2005. Performan kambing peranakan etawah (PE) di lokasi agroekosistem yang berbeda. Prosiding Seminar Nasional Teknologi Peternakan dan Veteriner. Pusat Penelitian dan Pengembangan Peternakan. Badan Penelitian dan Pengembangan Pertanian. Departemen Pertanian, Bogor, 650-659.

Devendra, C. dan Burns, M. 1994. Produksi kambing di daerah tropis. Bandung: Institut Teknologi Bandung Press.

Habib, I., Suprayogi, T. H dan Sambodho, P. 2014. Hubungan antara volume ambing, lama massage dan lama pemerahan terhadap produksi susu kambing Peranakan Ettawa. Animal Agriculture Journal, 3(1), 8-16.

Hendrich. C. 2008. Best management practicesfor dairy goat farmers. University of Wisconsin Emerging Agricultural Markets.

Jarmuji. 2011. Nilai korelasi antara ukuran badan dan ambing induk domba lokal Jonggol terhadap produksi susu. Agrinak, 1(1), 52-55.

Mardhianna., Dartosukarno S., dan Dilaga, W. S. 2015. Hubungan antara ukuran-ukuran badan dengan bobot badan Kambing Jawarandu jantan berbagai kelompok umur di Kabupaten Blora. Animal Agriculture Journal, 4(2), 264-267.
Mukhtar, A. 2006. Ilmu produksi ternak perah. Surakarta: UNS Press.

Pasaribu. A., Firmansyah danIdris, N. 2015. Analisis faktor-faktor yang mempengaruhi produksi susu sapi perah di Kabupaten Karo Provinsi Sumatera Utara. Jurnal Ilmu-Ilmu Peternakan, 18(1), 28-35.

Pribadiningtyas, P. A., Suprayogi T. H., dan Sambodo P. 2012. Hubungan antara bobot badan, volume ambing terhadap produksi susu kambing perah laktasi Peranakan Ettawa. Animal Agricultural Journal, 1(1), 99105.

Ramadhan, B. G., Suprayogi. T. H. dan Sustiyah. A. 2013. Tampilan produksi susu dan kadar lemak susu kambing Peranakan Ettawa akibat pemberian pakan dengan imbangan hijauan dan konsentrat yang berbeda. Animal Agriculture Journal, 2 (1), $353-361$.

Saputra, Y., Sudewo, A.T. dan Utami, S. 2013. Hubungan antara lingkar dada, panjang badan, tinggi badan dan lokasi dengan produksi susu kambing sapera. Jurnal Ilmiah Peternakan 1(3), 1173-1182.

Solaiman, S. G. 2010. Goat science and production. USA: WilleyBlackwell. A John Wiley \& Sons, Inc, Publication.

Taofik A, dan Depison. 2008. Hubungan antara lingkar perut dan volume ambing dengan kemampuan produksi susu kambing Peranakan Ettawa. Jurnal Ilmiah Ilmu-ilmu Peternakan, 11(2), 59-74. 